\title{
Subsalt Depth Seismic Imaging and Structural Interpretation in Dumre Area, Albania
}

\author{
A. Jardin' 1 F. Roure' and L. Nikolla ${ }^{2}$ \\ 1 IFP Energies nouvelles, 1-4 avenue de Bois-Préau, 92852 Rueil-Malmaison - France \\ 2 National Agency of Natural Resources, Blloku Vasil Shanto, Tirana - Albania \\ e-mail: anne.jardin@ifpen.fr - francois.roure@ifpen.fr - I.nikolla@akbn.gov.al
}

\begin{abstract}
Résumé - Imagerie sismique profondeur sub-salifère et interprétation structurale dans la région de Dumre, Albanie - Le challenge de l'exploration pétrolière par la sismique réflexion dans les zones de montagne est d'obtenir des coupes capables de bien imager les structures géologiques profondes situées sous une couverture sédimentaire plissée. Cette série de sédiments peut être très complexe et engendrer ainsi de fortes variations latérales et verticales de vitesses sismiques. Dans ces régions, l'image sismique est souvent de mauvaise qualité et l'évaluation des profondeurs où se situent les réservoirs d'hydrocarbures potentiels reste délicate et imprécise. Ces difficultés proviennent d'une propagation complexe de l'énergie sismique à travers les lentilles déformantes des couches superficielles. Un ensemble de traitements sismiques, en particulier les migrations en profondeur applicables après et avant sommation, a été développé pour obtenir une estimation plus précise de la géométrie des couches et pour améliorer, dans de tels contextes géologiques, la construction du modèle structural en profondeur.

L'application conjointe de techniques combinant raisonnement géologique et imagerie sismique en profondeur peut améliorer la compréhension des déformations structurales et réduire les incertitudes sur le modèle en profondeur en décrivant le plus précisément possible la géométrie et les vitesses des couches géologiques. Nous avons établi une méthode interprétative et itérative pour effectuer cette imagerie sismique et fournir ainsi les images adéquates pour aider le géologue interprétateur dans l'élaboration d'un modèle structural plus réaliste. Nous avons appliqué cette méthode dans la région de Dumre, en Albanie. Cette région, qui fait partie du bassin Ionien situé dans la ceinture de chevauchement albanaise, se caractérise par une géologie complexe (présence de sel et tectonique compressive) et une imagerie sismique difficile. Le principal objectif de cette étude était de comprendre l'échec d'un forage profond et de proposer une nouvelle localisation pour la fermeture possible d'un réservoir carbonaté, situé sous un diapir de sel affleurant en surface. Cette étude est présentée ici pour illustrer les améliorations obtenues par l'application d'une démarche intégrée impliquant fortement géologues et géophysiciens et s'appuyant sur des outils de traitements sismiques disponibles mais requérant une prise en compte plus importante des données géologiques.
\end{abstract}

\footnotetext{
Abstract - Subsalt Depth Seismic Imaging and Structural Interpretation in Dumre Area, Albania The challenge of seismic exploration in fold and thrust belt settings is to optimize the depth seismic images of the deep structural objectives beneath a complex overburden that may show strong horizontal and vertical velocity variations. In such areas, the seismic image is frequently of poor quality and the depth models of deep layers is often false due to the perturbed propagation of seismic energy through the deforming lens of the overlying layers. A range of seismic processing tools, including post-stack and pre-stack depth migrations, are appropriate to predict the accurate geometry of deep target structures and to improve the building of a depth structural model.
} 
A strong combination of geological reasoning and depth seismic imaging processing can improve the understanding of the deep geological structures by reducing the uncertainties in depth geometrical and velocity model estimation. We propose an interpretative and iterative approach to the post stack depth migration method to guide the interpreter in the development of a reliable subsurface model. We have applied this approach during an exploration study in the Dumre area, located in the Ionian Basin (Albania) which is a complex fold and thrust belt. The main objectives of this study were to understand the failure of a former exploration well and to propose a new location for the potential closure of the carbonate structure. This subsalt imaging study aims at illustrating the improvements obtained by application of this integrated seismic imaging method especially in the evaluation of a subthrust prospect in a tectonically complex belt setting.

\section{INTRODUCTION}

Seismic structural interpretation in complex areas such as faulted, folded and thrust zones is particularly difficult when it is based on conventional time seismic sections. These time images often show a distorted representation of the real subsurface geometry even after the application of time migration processing. This is due to complex propagation of the seismic signal and energy through the structured overburden. The distortion of the seismic signal can also be affected by the presence of large lateral velocity variations generated by lithological layer characteristics (Jardin et al., 2005).

In such setting, the objectives of the seismic tools is to produce seismic images to "see the invisible beneath foothills structures" (Gray et al., 2002), that is to say, firstly to perform the displacement of misplaced reflections and the focussing of diffractions generated by faults and discontinuities and then, to be able to accurately estimate the depth location of the potential reservoirs. Presently, to reach these objectives, the most sophisticated processing technique is pre-stack depth migration. But this technique, which is now available for $2 \mathrm{D}$ and $3 \mathrm{D}$ applications on pre-stack seismic gathers, remains costly and requires difficult interpretation work in particular to estimate the depth velocity model, especially for onshore exploration (Albertin et al., 2002). To cope with these limitations, post-stack depth migration techniques offer an alternative processing flow even if the assumptions of the simplified theory of the seismic stack based on the common mid point geometry and multiple fold coverage are commonly violated in complex structured areas. Nevertheless, if the main objective of the seismic data is to obtain seismic images which can help the interpreter to establish reliable and realistic structural models of the subsurface, post-stack depth migration is still a quick and efficient processing tool which can be easily applied to test the different hypotheses proposed by the interpreter (Cabrera et al., 1998). To obtain reliable results, both seismic processing and interpretation tasks must be done iteratively and require strong integration between the geologist and the geophysicist. We have applied this workflow to several case studies, in various foothills areas worldwide (Jardin and Collaku, 2004; Jardin et al.,
2005; Bêche et al., 2005). The workflow has been applied to the Dumre block which is characterized by a complex geological environment involving a salt diapir and thrust structures and the results are presented here to illustrate the benefits of the workflow for oil and gas exploration.

The regional geology and hydrocarbon exploration of Albania will be reviewed to provide the context for the geological setting of the Dumre area, which is in the Ionian basin in the central part of Albanian thrust belt. The Dumre area is structurally complex which is characterized by a large scale salt body outcropping at surface. The depth seismic imaging workflow is described in detail including the depth seismic images associated with depth velocity models. Finally an improved structural interpretation is proposed based on these seismic images, which leads to new potentially prospective drilling targets in this region.

\section{GEOLOGICAL BACKGROUND}

\subsection{General Information on Albanides}

\subsubsection{Regional Geology}

Albania forms part of the Dinaric-Albanic-Helenic arc of the Alpine orogen, the formation of which occurred mainly during the Tertiary and gives the country its mountainous relief. From a geological point of view, Albania is a typical foreland fold and thrust belt system: the mountain front and the foreland fold belt of Albanides include all the main elements of thrust systems worldwide, including drag folds on thrust faults, backthrusting, passive roof duplexes and triangle zones. Structurally, the mountains are divided into the Internal and the External Albanides. Figure 1 shows the structural map of central and southern Albania.

The Internal or Inner Albanides consist partly of ophiolites. The External Albanides are divided in different zones separated by thrusts and characterized by Triassic to Eocene carbonate facies and Oligocene to Pliocene silico-clastics. The zones are, from east to west, the Kruja platform zone and further to the west, detached on top of Triassic evaporites, the 


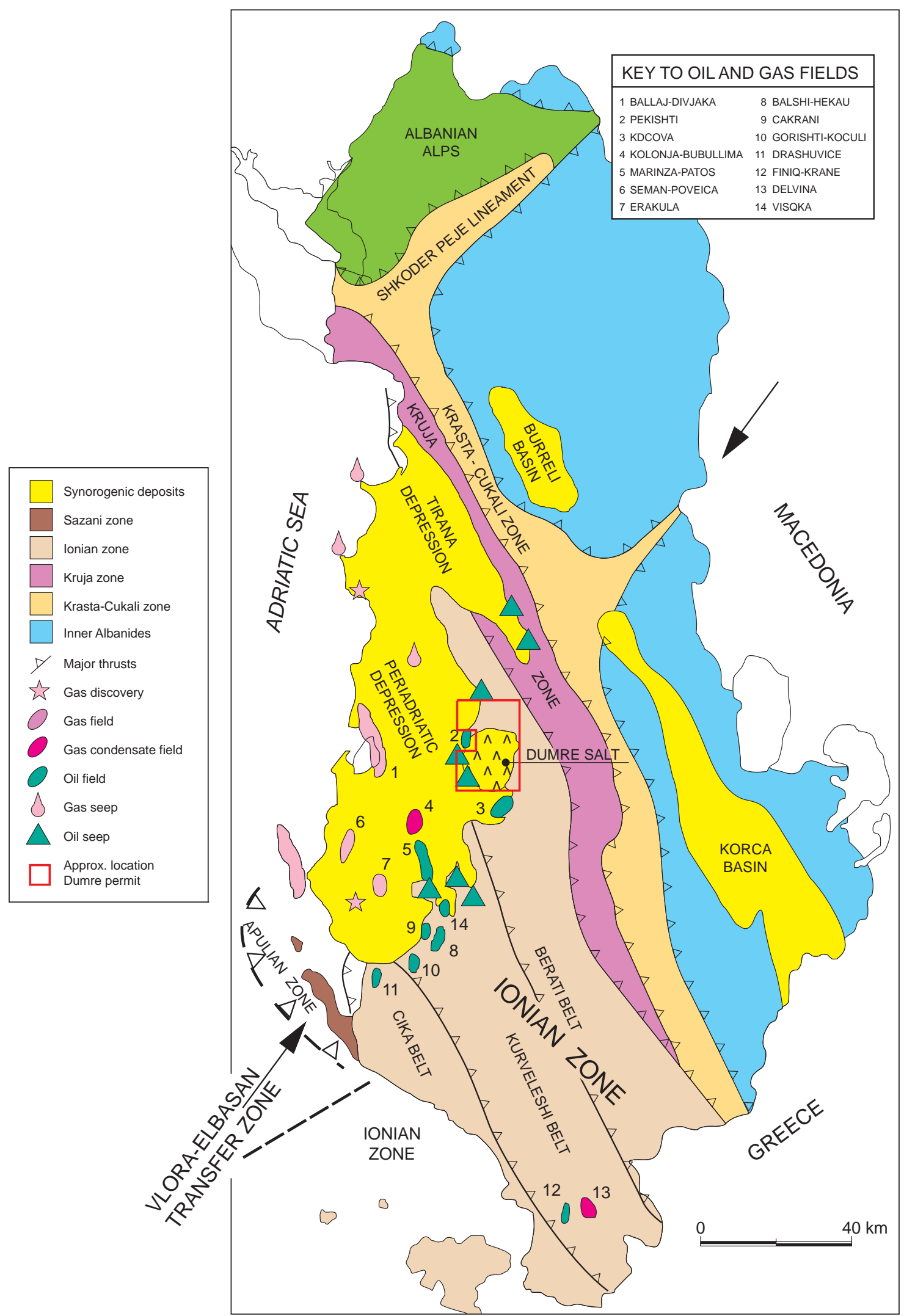

Figure 1

Structural map of central and southern Albania with the location of the Dumre block and main oil and gas fields around this area (modified from Roure et al., 2004). 
Berati belt, the Kurveleshi belt and the Cika belt which form together the Ionian zone and consist of pelagic limestones (Roure et al., 2004) (Fig. 1). The westernmost cape of the Albanian coast is formed by the Sazani zone, which is an eastverging thrust involving the Apulian platform (Nikolla et al., 2002).

Major strike lineaments are present controlling the sedimentary infill and the tectonic style in the Albanides. The Vlora-Elbasan lineament roughly delineates the northern boundaries of the Cika belt, Kurveleshi belt and Berati belt and forms also the southern boundary of the Peri-Adriatic Depression (Fig. 1).

\subsubsection{Oil and Gas Exploration}

The northern part of the Ionian Zone is characterized by the occurrence of numerous productive oil, gas and gas condensate fields, as well as yet untested prospects. Presently, the Cretaceous-Eocene carbonate sequence sealed by the Oligocene flysch is the main target of hydrocarbon exploration in the Albanian thrust belt. Some of the fields located in carbonates, are involved into the tectonic deformation where the Tertiary overburden is present, notably along the VloraElbasan transfer zone which separates the Peri-Adriatic depression in the north from the Ionian basin to the south, and extending from the External Albanides in the west, to the Inner Albanides in the east (Fig. 1). The interplay between evaporites and carbonates can significantly control the seal characteristics of the reservoir and influence the deformation and the diagenetic and thermal conductivity processes. The mountainous relief provides excellent outcrop information on the carbonate reservoir rocks and the marl and clay top seal. Due to the large scale overthrusting, new hydrocarbon prospects are expected in the subthrust domain. Many dry wells were drilled however on promising exploration targets probably due to difficulties in interpretation of seismic images in the time domain alone, and to insufficient geological control from deep wells (Gjermani and Dhima, 2009).

\subsection{Major Lithostratigraphic Units Around the Dumre Block}

The Dumre block is located at the boundary between the Peri-Adriatic depression and the presently inverted Ionian basin, along the major Vlora-Elbasan lineament (Fig. 1). The synthetic stratigraphic columns of both Ionian and adjacent Kruja zones are presented in Figure 2. The stratigraphic column of the Ionian zone is composed of Upper Triassic evaporites, Upper Triassic to Eocene carbonates, Oligocene flysch, lower Miocene to Serravallian premolasse and Tortonian to Pliocene molasse (Fig. 2).

Because the northern and southern External Albanides differ greatly and because the Dumre block is located at the boundary between these two provinces, we shall describe here two reference cross-sections, one immediately north of Dumre, and the other one just to the south (Fig. 3) (Roure et al., 2004).

\subsubsection{Major Units North of the Dumre Block}

From west to east, two distinct tectonostratigraphic domains of major interest for petroleum exploration can be distinguished (Fig. 3, cross-section A-A').

\section{The Peri-Adriatic Depression}

In the west, the Peri-Adriatic depression is characterized by a thick synflexural or synkinematic terrigenous sequence and includes both Oligocene flysch and Miocene-Pliocene molasse series. Despite the fact that its pre-orogenic Mesozoic and Eocene substratum has not yet been drilled, it is assumed to be of basinal type. It is probably very similar to the Ionian basin in the south or to the offshore Adriatic province. However, unlike the Ionian basin, no detachment is known to occur here in the basal Triassic sequence, indicating a major lateral facies change with a progressive disappearance of the evaporites from the south (Ionian basin) to the north (Peri-Adriatic depression). Nevertheless, both the Oligocene flysch and the Neogene shales of the Peri-Adriatic depression were locally activated as major detachment levels at the front of the External Albanides. Exploration for biogenic gas is being actively pursued in the clastic reservoirs of the Mio-Pliocene sequence.

\section{The Kruja Platform Duplexes}

Duplexes of the Kruja carbonate platform have been recognised by drilling and constitute two additional surface trends, i.e. the Makareshi trend and the Daiti Mountains, the major and outermost relief involving Mesozoic carbonates in northcentral Albania. Outcrops and well data indicate that the Kruja duplexes are probably detached from their pre-Cretaceous substratum along intra-Cretaceous shale horizons, as no Jurassic or Triassic rocks have ever been found in these structures. Cretaceous and Paleocene-Eocene sequences relate to shallow-water platform carbonates, with frequent hiatuses, flooding, erosional surfaces and even bauxitic horizons. Transgressive deep-water Oligocene turbiditic flysch sequences attest to the progressive flexing of the former Kruja platform as it entered into the Albanides foredeep in Paleogene times, soon after the obduction of the ophiolites in the inner parts of the belt. Unconformable Tortonian to Pliocene horizons were locally trapped in piggyback basins that overlay the Kruja duplexes, recording a progressive tectonic emplacement of these thin-skinned structures during Neogene times. Although no oil has yet been produced from the Cretaceous carbonate reservoirs in this region, numerous oil seeps are known at the base of the Neogene unconformity and are probably sourced from a deeper but active petroleum system with a possible mature source rock in the Cretaceous series. 


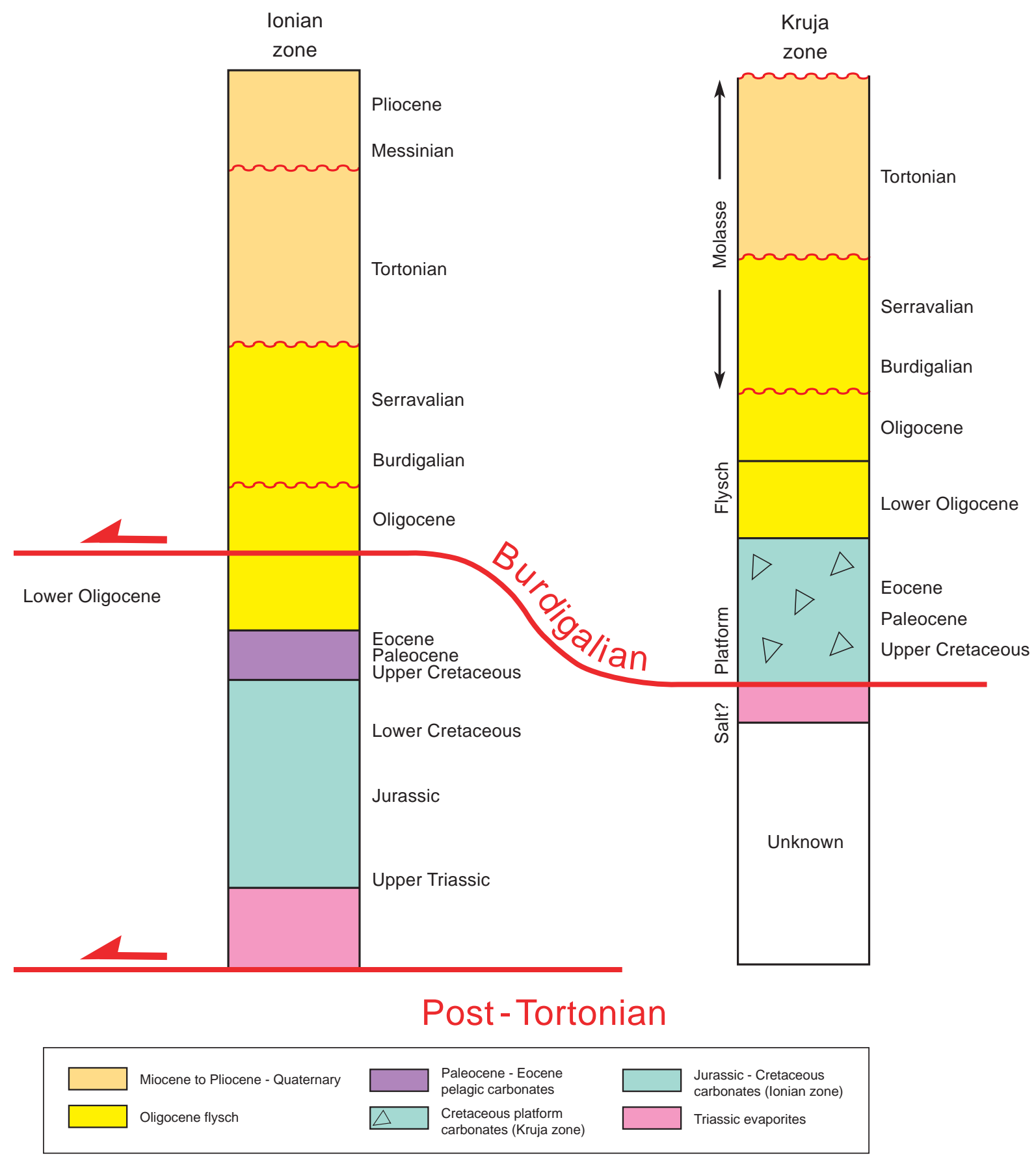

Figure 2

Synthetic stratigraphic column of the Ionian zone and the adjacent Kruja zone.

\subsubsection{The lonian Basin Units, South of the Dumre Block}

South of the Vlora-Elbasen lineament, the Ionian basin is presently dissected by four major thrust units, i.e. the CikaTragjasi belt, the Kurveleshi-Ftera belt, the Mali Gjere and the Berati belts (Fig. 1). Unlike in the northern External
Albanides province, the Triassic evaporites constitute the major detachment level in this region. Jurassic shales (Posidonia Schist) and Oligocene flysch sequences act also locally as secondary disharmonic levels (Fig. 3, cross-section B-B'). The Triassic salt has also generated huge diapirs, 

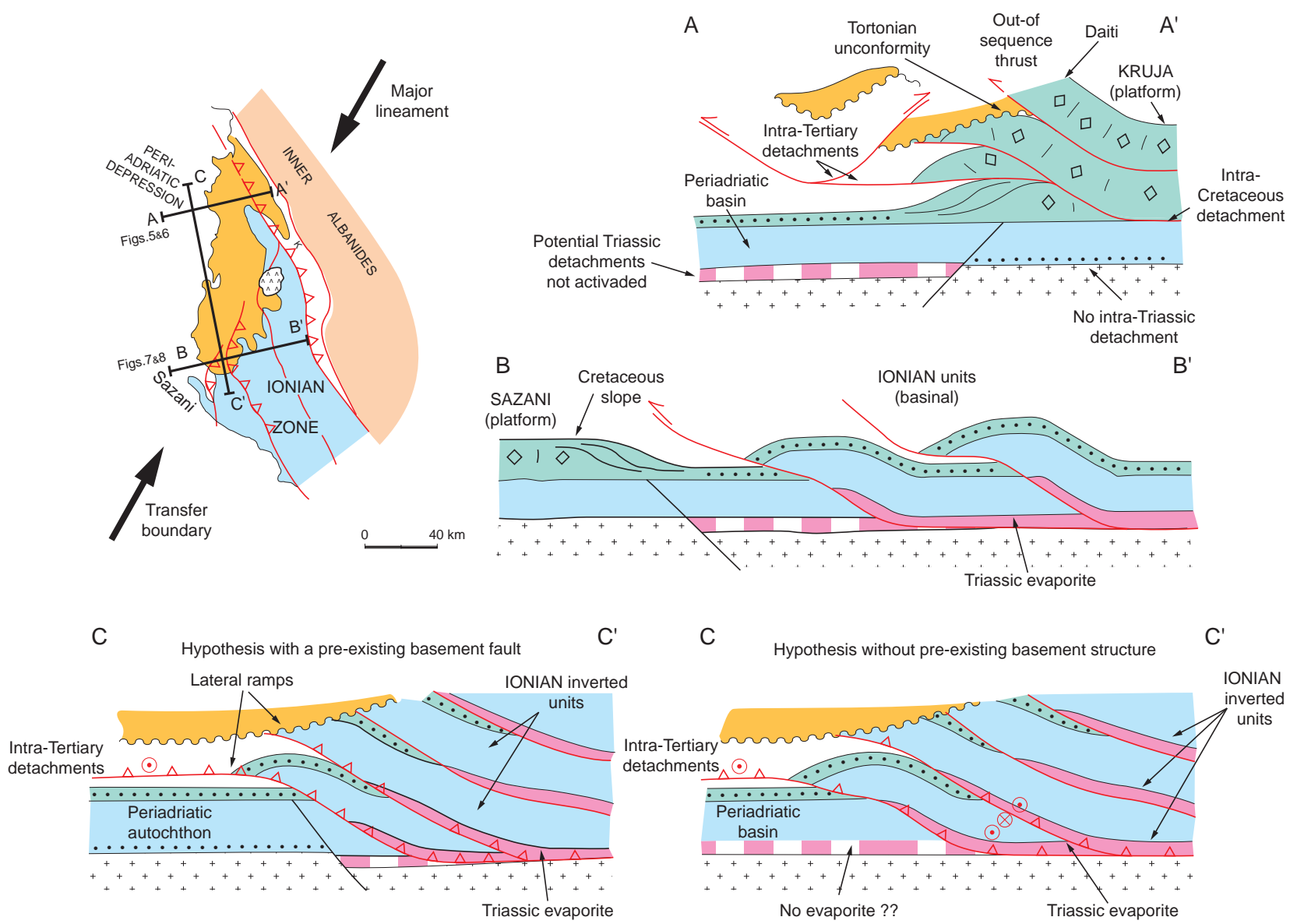

Figure 3

Structural sketch around the Dumre block and depth interpretation of the Vlora-Dumre transfer zone (modified from Roure et al., 2004).

which are now most frequently unrooted, being transported piggyback on the basal detachment together with the allochthon (Velaj and Xhufi, 1995). The Ionian zone in Albania is characterized by great thickness and facies changes in the Upper Triassic to Liassic series, indicating the occurrence of tilted blocks (late Triassic to Liassic dolomite or platform carbonate) and confined sub-basins (organic rich Toarcian Posidonia Schist). Two dark chert horizons are widespread in the Dogger and Upper Jurassic sequences (Roure et al., 2004). Together with two intra-Cretaceous phosphatic horizons, respectively Turonian and early Senonian in age, these series constitute a set of parallel regional marker beds that lie unconformably above the contrasted architecture of underlying horsts (white limestones) and grabens (dark shales) of the synrift sequence (Fig. 3).

Slumps and carbonate turbidites are frequent in the Upper Cretaceous-Paleocene, whereas fine grained white to pink pelagic carbonates (scaglia) constitute most of the Eocene sequence. Open fractures frequently improve the reservoir quality of these Upper Cretaceous to Eocene carbonates and the overlying Oligocene flysch sequence constitutes a very good seal. Potential source rocks are known both in Upper Triassic or Liassic bituminous dolomites and in the Toarcian Posidonia Schist.

\subsubsection{Synorogenic Tertiary Sequences and Timing of the Deformation in the External Albanides}

Synflexural deposits become progressively younger westward, with the first flysch being Upper Cretaceous to Eocene in age in the east (Krasta units) and no older than Oligocene in the Ionian and Kruja domains. Additional flexural deposits were deposited during the Neogene in the Periadriatic depression and on top of the Sazani area (Roure et al., 2004). Similarly, the onset of the compressional deformation is oldest in the east, i.e. late Jurassic obduction of the Mirdita ophiolite and becomes progressively younger in the west, with the Pliocene infill of the Peri-Adriatic depression being largely backthrusted over the Kruja duplexes. Most deformations in the Ionian basin and the thrust emplacement of the Kruja 
duplexes are nevertheless best interpreted as resulting from a continuum of deformation, lasting from Burdigalian to Pliocene time. Diachronous unconformities at the base of the piggyback basins and progressive tilts of the synkinematic sediments effectively record ongoing deformation (Roure et $a l ., 2004)$. Restoration of balanced cross-sections to their preorogenic, palinspastic geometries helps in estimating the amount of Neogene shortening but only accurate forward modelling techniques provide additional constraints on kinematics, such as the velocities along individual thrust faults (Roure et al., 2004).

\subsection{Structural Styles of the External Albanides}

Although most of the present-day architecture of the External Albanides and their foreland relates to Neogene compressions, some pre-existing extensional structures are still preserved in the autochthon, or were passively transported in the allochthon.

\subsubsection{Pre-existing Jurassic Extensional Structures}

Lower Jurassic extensional structures, i.e. normal faults and tilted blocks inherited from the Tethyan rifting, are especially well preserved in the Ionian units. During the inversion of the basin, only those faults whose spacing and orientation were consistent with the Neogene maximum principal stress (sigma 1) were reactivated. The majority of the Jurassic normal faults, which trend at a high angle with the Neogene thrust fronts, were detached from their pre-Triassic substratum along the Triassic evaporites or the Toarcian black shales, and subsequently, passively transported in the upper plate. As a result, the present-day structural grain of the Ionian zone is largely inherited from the Jurassic one, but surface cover structures are normally disconnected from their initial basement roots. The frequent occurrence of volcanics or metamorphic rocks in the diapirs or along major thrust fronts in the Ionian zone indicates that most Jurassic faults involved the basement, prior to being truncated during the Neogene episodes of deformation. Alternatively, basement short-cuts could have taken place during the inversion tectonics near the crest of former tilted blocks, and would account for the remobilisation of basement highs during Neogene times.

\subsubsection{Decoupling Horizons and Thin-skinned Structures}

Four major detachment levels have a regional distribution and account for most thinskinned structures observed, i.e. the thrust sheets, antiformal stacks of duplexes and triangle zones. They comprise:

- the Triassic evaporites, which constitute the basal detachment beneath the Ionian allochthon;

- the Toarcian Posidonia Schist, which constitutes a secondary, shallower potential detachment in the Ionian basin, when present;
- the hypothetical intra-Cretaceous evaporites of the Kruja platform, which comprises only Cretaceous and younger horizons, being entirely detached from its former infraCretaceous substratum;

- the Oligocene flysch and the Neogene shaly interbeds, which constitute the only potential detachments at the deformational front in the Periadriatic depression.

\subsubsection{The Vlora-Elbasan Transfer Zone and Changes in the Detachment Levels in the Vicinity of the Dumre Block}

The deformational front is abruptly displaced westward between the Peri-Adriatic depression in the north and the Ionian basin in the south, whereas the front of the Internal Albanides remains approximately linear farther east, precluding any lateral change in the overall amounts of Neogene shortening between the northern and southern parts of the External Albanides (Roure et al., 2004) (Fig. 1). This rapid jump or curvature of the External Albanides thrust front implies the existence of a transfer zone, which parallels the major NE-trending Vlora-Elbasan or Lushnje-Elbasan lineament. Although no thrust or tear faults trend in the same direction at the surface between the Ionian units and PeriAdriatic basin, this structure has a clear regional meaning and probably results from the reactivation of a major paleogeographic boundary. When comparing this peculiar structural pattern with results of analogue models of thrust propagation in anisopachous stratigraphic sequences, two distinct but complementary hypotheses can be proposed to account for the changes observed in the thrust architecture, with a steep and relatively narrow accretionary wedge in the north (Kruja duplexes and Peri-Adriatic depression) and a wide but smoother wedge in the south (Ionian basin) (Roure et al., 2004). The first parameter that can induce such a change in the geometry of the thrust front is the depth to the basal detachment. For the same amount of shortening, the deeper the detachment is, the wider the thrust units are. The second parameter relates to the coupling (friction) along the basal detachment. Thrusts propagate faster and further in plastic horizons, i.e. evaporites, than in brittle materials, i.e. shale and sand interbeds. From observation of the subsurface data, it appears that the basal detachment does remain shallow in the Oligocene flysch and even in the Neogene clastics in the north beneath the Peri-Adriatic depression, whereas it is deeper, in the Triassic evaporites, beneath the Ionian basin. Thus, the lineament probably represents a major intraTriassic structure, with the disappearance of the Triassic evaporites northward beneath the Peri-Adriatic depression.

\subsubsection{Triassic Evaporite Formations}

The presence of large evaporite outcrops at Dumre and at other various outcrops in Albania (Gline, Kardhiq, Vermik, etc.) gives evidence of deposits of Triassic evaporites which 
constitute the substratum of the Albanide foreland fold and thrust belt. All the outcrops result from evaporite mobility caused by the stress regime as the folds and thrusts developed. They occur where there is low lithostatic pressure in tectonically active areas where longitudinal faults intersect transverse faults. These faults occurred during the rifting stage and were inverted during the compressional stage. The evaporites of the Ionian zone outcrop both along the regional tectonic faults (e.g. in Dumre) and local structures (e.g. in Delvina). These formations constitute a perfect detachment level. Prospective carbonate structures for hydrocarbon exploration are evidenced under the evaporites through seismic profiles acquired in this region (Velaj, 2001).

\section{DEPTH SEISMIC IMAGING STUDY}

\subsection{Depth Imaging Workflow in Fold and Thrust Belt Setting}

\subsubsection{Limits of Time Processing and Vertical Depth Conversion of Seismic Lines}

Fold and thrust belt areas are characterized by folded and faulted sedimentary layers of great complexity, associated with highly variable topography. Seismic exploration in such settings requires modified acquisition and processing techniques, due to strong lateral and vertical velocity variations. The resulting seismic information is usually displayed either as a time stack section or a time-migrated section. Time migration processing is used to focus the seismic energy diffracted by faults and to place dipping structural events in the right time location. However, in the case of a highly structured subsurface, it results in seismic images which can be far from the geological reality. Depth conversion of seismic data provides more realistic images of the structural features. Simple time to depth conversion of the seismic section requires the input of mean vertical velocity values related to the characteristics of the subsurface layers. The vertical time to depth conversion technique transforms time information into depth values but assumes no lateral velocity variations. When these variations are strong, depth migration processing is required to obtain a reliable seismic image (Robein, 2003). Depth migration can be viewed as a two step procedure. The first step is to focus the diffracted energy, as for any migration processing. The second step is to convert the seismic data from the time domain to the depth domain. In the case of a complex structural setting, the pre-stack depth migration technique provides the best seismic images in terms of geometry but presents the disadvantage of being both costly and time-consuming. Post-stack depth migration can be a feasible alternative if the conventional stack sections can reasonably be considered to represent zero-offset sections or if coherent seismic reflectors remain visible. Both pre-stack and post-stack depth migration techniques directly provide depth seismic images, but require the construction of a detailed structural depth model describing the geometry of the geological layers and the intra-bed velocity variations in the depth domain. This depth velocity model is especially uncertain in structured zones and can be computed with advanced pre-stack inversion techniques. When pre-stack seismic data are unavailable, it is difficult to immediately define a reliable depth velocity model from stacked seismic data only. Poststack depth migration application therefore becomes an interpretative processing technique, requiring several iterations between the seismic interpreters and processors.

\subsubsection{Interpretative Post Stack Depth Migration}

The depth structural model must describe the main geometric and lithological features of the subsurface. In salt and thrust belt setting, the determination of a structural depth model from post stack seismic data must be the result of combination of both geological knowledge and of seismic techniques requiring a structured approach (Fig. 4): the "interpretative post stack depth migration" workflow which aims at determining a coherent structural depth model from seismic and geological data.

\section{Initial Interpretation Steps}

The first step of the method is to delineate the target area and to identify the structural objectives of the study. This objective could be the recognition of hydrocarbon structural traps, the improvement of appraisal well targets or improved understanding of tectonic styles. In foothills areas, the importance of velocity model determination within near-surface layers for deep seismic image improvement is well known (Muller et al., 2000). Field studies and regional geological maps can yield important information on surface dips and lithologies. Information from wells, when available, also contributes to the depth velocity model of the drilled layers: depth values used for seismic calibration, velocity and lithology values from logs. The comparison of already processed seismic time images provides an identification of seismic shadow areas, an estimation of the structural sensitivity to post stack time migration velocities and an evaluation of the influence of near-surface layers on the propagation of the seismic signal (signal to noise ratio, consistency of seismic static corrections, etc.). Conventional time structural interpretation is carried out in order to obtain an initial structural depth model, by map migration of seismic horizons or by simple layer-cake conversion of the interpretation. Based on these initial processing and interpretation results, the subsurface is divided into zones related both to structural complexity (from light to heavily faulted zones) and to seismic imaging assumptions (from moderate to strong lateral velocity variations). 


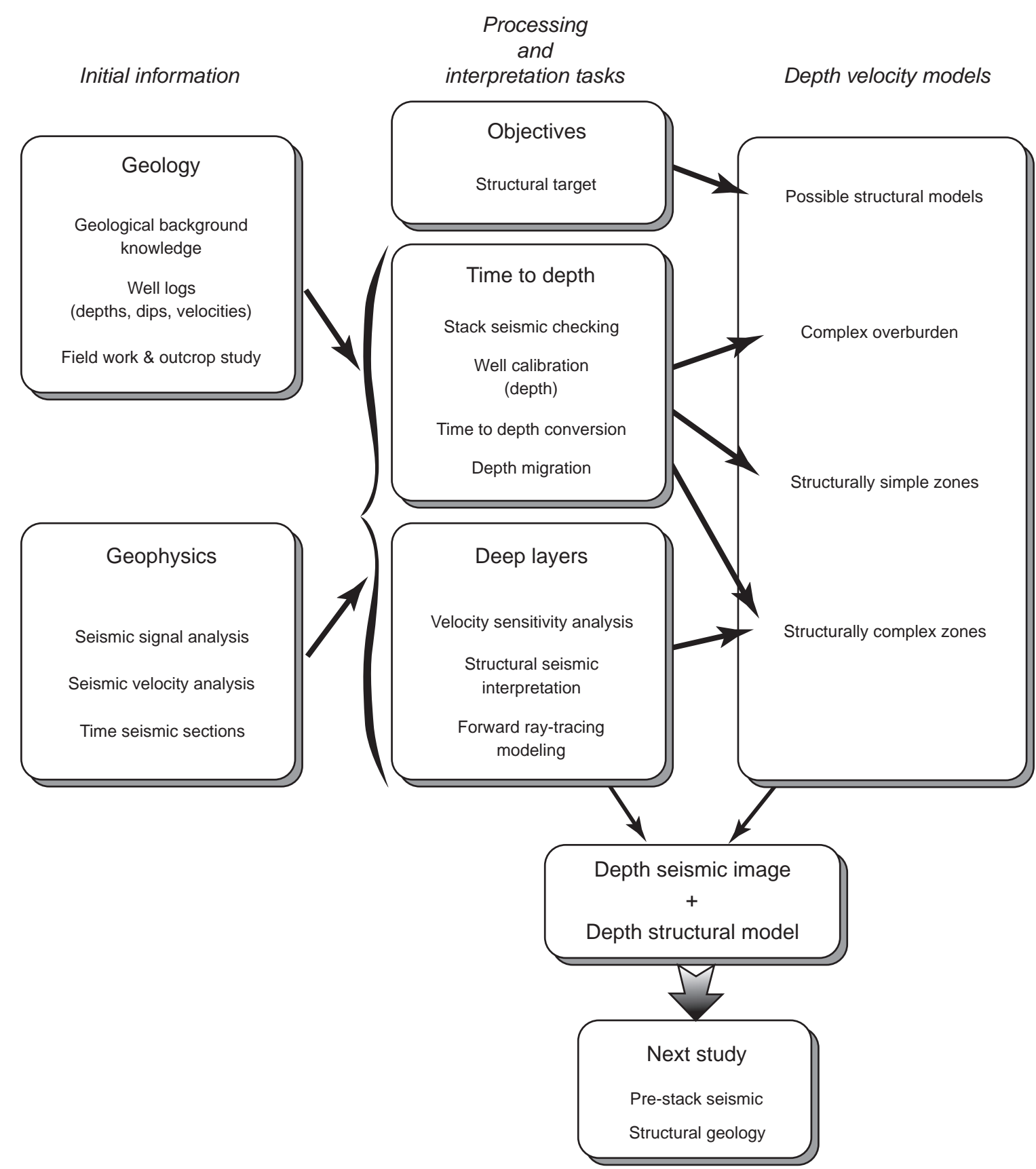

Figure 4

Interpretative seismic depth imaging workflow.

\section{Iterative Depth Migration Steps}

A step by step method of depth velocity model building is then applied, working from the previously delineated simple zones towards more complex zones. After the development of a reliable model for the complex overburden, post-stack depth migration processing is applied using this depth model. For deep and structurally complex target formations, when depth and velocity calibrations from well data are absent, the strategy for structural model evaluation is essentially based on seismic depth migration processing. Because velocity variations and structural features can only be deduced from seismic data and geological reasoning at this stage, analysis of the sensitivity of seismic images to the different structural assumptions is necessary. Various velocity variations for deep layers are simulated in order to compare the computed depth images and to quantify the uncertainties related to the 
velocity parameters. Thus the selection criteria for choosing a geologically and seismically consistent model are given by an interpretative comparison between the different depth images. For each zone, iterations between geological interpretations and seismic processing techniques ensure a coherent structural depth model. We retain the best seismic images of the main structural features such as fault zones and an optimal depth model is chosen after consistency control of the time and depth images obtained by forward modelling and consistency control between the depth velocity model and its associated depth seismic image. The improvement of the seismic energy focussing by comparison with time migrated images is an additional selection criterion.

\section{Final Structural Interpretation}

Finally, the computed seismic depth images are interpreted, resulting in the best geological and geophysical depth structural model that can be obtained from this post-stack seismic study. In addition, the results could be subsequently used as an initial velocity model for pre-stack seismic imaging processing such as travel time inversion and pre-stack depth migration (Bêche et al., 2005).

\subsection{Application to Dumre Seismic Data}

\subsubsection{Initial Interpretation}

The Dumre evaporite represents a salt dome with a surface area of $210 \mathrm{~km}^{2}$, which outcrops with an elliptical shape with axes of $20 \times 10 \mathrm{~km}$ (Fig. 5). In depth, the evaporite body has a diapiric shape with a thickness of $6.1 \mathrm{~km}$ and a westward overthrust displacement of more than $20-30 \mathrm{~km}$. Its volume is over $1500 \mathrm{~km}^{3}$. Numerous seismic surveys have been recorded in this area amounting to hundreds of kilometres of data. Figure 6 shows the time migrated section AAP-06-96 (line 6) as an example of time images obtained after conventional time processing. The salt layer is recognized both by the lack of seismic reflections inside the diapir and by the presence of stronger seismic amplitudes at the base of the evaporite body. Below the evaporite, seismic reflections are interpreted as the prospective carbonate subthrust platform but its precise geometry cannot be easily determined due to the lack of continuity of these seismic events. The time map of the evaporite base has been estimated and combined with the geological surface map where Dumre diapir boundaries are well recognized (Fig. 5). The features of this diapir recognized through field outcrop studies could provide a better understanding of the geometry of the underlying Mesozoic carbonates of the Ionian allochthon. Many wells have been drilled in the past within the Dumre block or in its vicinity but provide information only on the velocities of the Oligocene flysch and Neogene. In 1995, the Dumre-7 well drilled through the salt diapir, the parautochthonous Oligocene flysch series being ultimately reached beneath the allochthonous salt at a depth exceeding $6 \mathrm{~km}$ (Fig. 7). This well is located in the centre of the study area, close to the intersection of lines AAP-11-96 and AAP-06-96. Unfortunately, the well was abandoned before reaching the carbonates. Vertical seismic profile data was recorded in the Dumre-7 well but this data was recorded when the well was still within the salt body, not at the Total Depth (TD). Therefore, these data were only able to predict the depth to the base of the salt, precluding any direct computation of the depth to the carbonates (Fig. 7). Using a mean velocity value of $5 \mathrm{~km} / \mathrm{s}$, the depth range of evaporites could be estimated from 5500 to $7500 \mathrm{~m}$ in this area. The Dumre-7 well was drilled at the location of the assumed minimum depth for the base of evaporites. The initial model was built based on this initial interpretation of the salt diapir features and the recognition of the overburden layers.

\subsubsection{Depth Migration}

Although reliable velocity information and accurate geometrical features of the infra-salt series are still lacking, a calibration of the seismic on the Dumre-7 well was a pre-requisite for the depth migration. Only the seismic lines of the 2D survey of $60 \mathrm{~km}^{2}$ size acquired in 1996 have been reprocessed by depth migration (Fig. 5). Therefore, two lines, line AAP-1196 and line AAP-06-96, the most recent ones crossing the Dumre-7 well and oriented N-S and E-W were processed first (Fig. 5). In order to evaluate the ability of depth migration techniques to decipher the complex architecture of the Ionian structures beneath the Dumre salt, six other E-W trending lines and four other N-S trending lines have been reprocessed later, according to the velocity values defined from the two first lines.

Good seismic imaging and confident time to depth conversion are particularly difficult in the External Albanides because of the strong lateral velocity variations: from 2500 $2800 \mathrm{~m} / \mathrm{s}$ in the Miocene-Pliocene clastics to $5000-5500 \mathrm{~m} / \mathrm{s}$ for the evaporite and carbonate layers, resulting in distorted time seismic sections as it is shown in Figure 6, where the differences between non migrated and migrated time images are clearly visible. Therefore, lateral velocity changes in the overburden, between the low-velocity molasse deposits in the west and north and high-velocity salt in the south and east result in a complex seismic image, juxtaposing pull-down and pull-up effects in the time sections (Fig. 6). For this case study, a layer-cake velocity model was built integrating all velocity and depth data from shallow and deep wells, and modified velocity analysis based on the selected criteria explained in the previous section. Lateral velocity variations were modelled using a lateral constant gradient for velocity parameterization in several layers when lithological boundaries were difficult to accurately track. Control of the main structural features was performed by integrating regional geological knowledge. In Figure 8, the depth velocity model estimated for the line AAP-06-1996 is shown as an example of velocity models built for all the lines. In the upper part of 


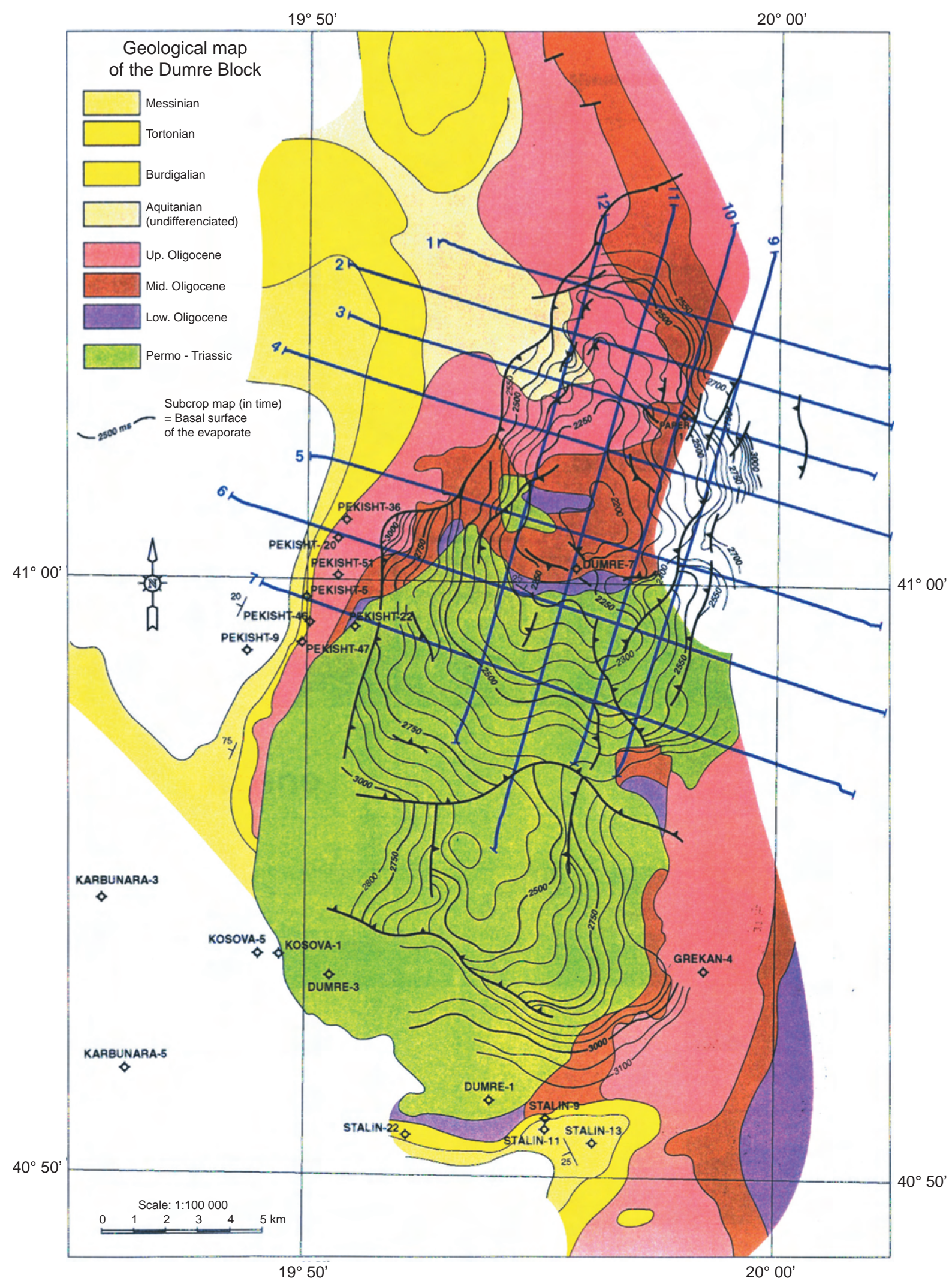

Figure 5

Geological map of the Dumre block, with the location of wells and seismic profiles used in this study. The lines indicate the isochronous lines of evaporite base from time seismic interpretation. 

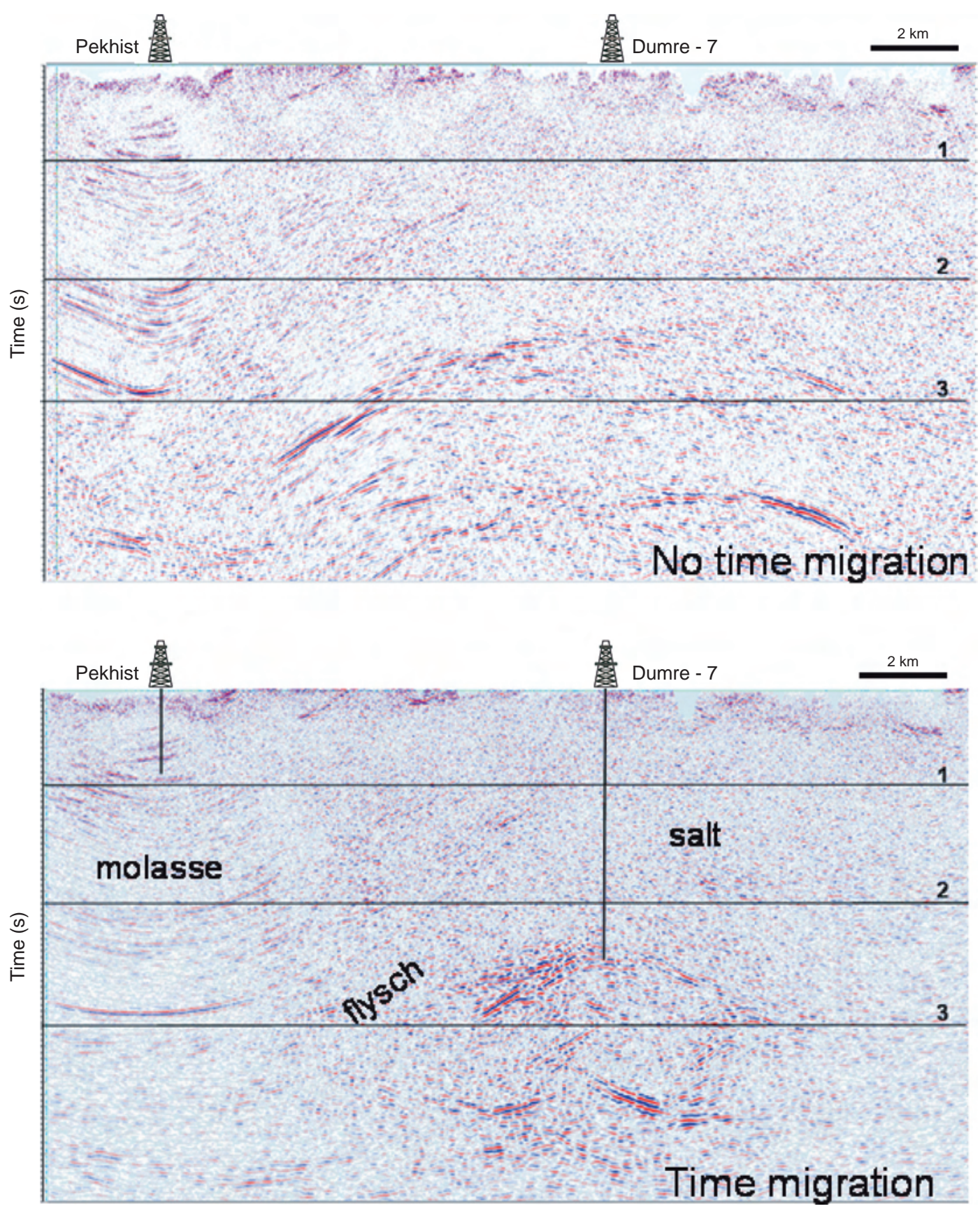

Figure 6

Time seismic images for the line AAP-06-96, before (upper) and after (below) time migration processing application.

the sections, depth structural models were built using available regional well data and the geological map of shallow formations (Pekisht 51, Paper-1, Peqini-2 in the western part of the study area and Dumre-7, in the central part, Fig. 5): these data were essential in ensuring the consistency and the reliability of depth migration results (Tab. 1). Therefore, it was necessary to accurately describe the contours of the flysch/ salt boundary in the structural depth model prior to further attempts at depth migration processing. Iterative migration tests have shown that the geometrical limits between the low velocity sediments (Neogene molasse, Oligocene flysch) and the high velocity salt body were critical to obtain a correct 


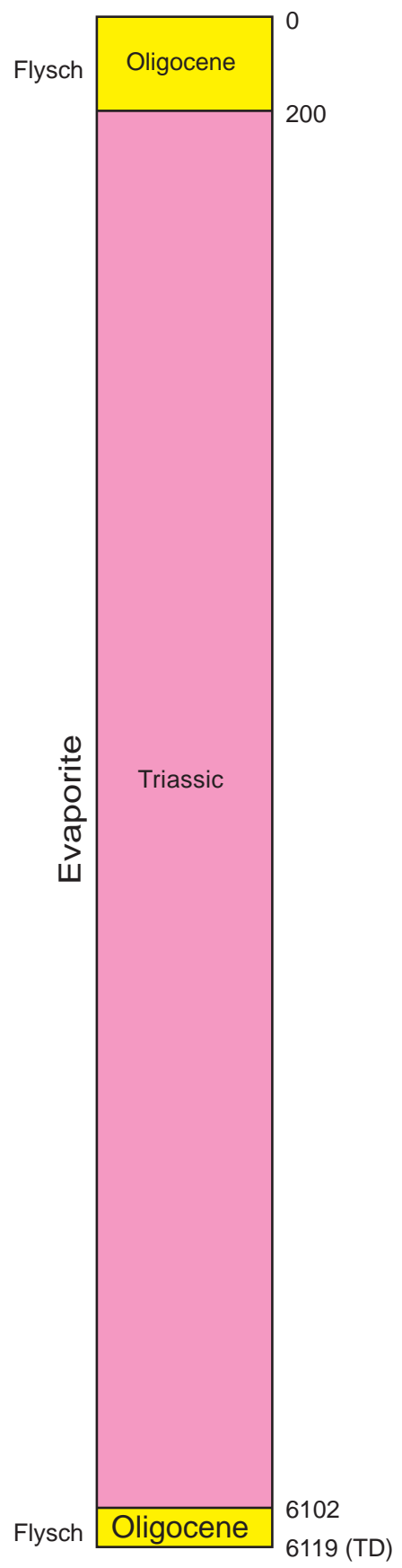

Figure 7

Summary schematic log of the deep Dumre-7 well.

depth seismic image. Simple zero-offset seismic modelling has demonstrated that the stack seismic response of sediments below the salt directly relates to the geometry of the salt/ flysch velocity boundary. This lithological velocity boundary effectively accounts for strong deviations of the seismic ray propagation.
TABLE 1

Estimation of layer velocity variations from regional well data

\begin{tabular}{c|c}
\hline Formations & Layer velocity range $(\mathrm{m} / \mathrm{s})$ \\
\hline Post-Messinian deposits & $2400-2700$ \\
\hline Neogene molasse & $3500-3800$ \\
\hline Olygocene flysch & $4000-4200$ \\
\hline Upper Triassic salt & $5200-5600$ \\
\hline Ionian carbonates & $5000-5700$ \\
\hline
\end{tabular}

For the deeper carbonate units, depth model construction was based solely on geological conceptual models and geophysical interpretation, as no well control was available for these depth intervals (apart from the Triassic-Oligocene boundary intersected by the Dumre-7 well). Thus, determination of an accurate seismic image was necessarily limited due to the poor control on geological assumptions. Only one velocity boundary was introduced into the depth model, to account for a potential velocity contrast (assumed to bean abrupt decrease of the velocity) between the salt base and deeper reflections, in association with moderate lateral velocity variations. The quality of the lower part of the sections (i.e. below $6 \mathrm{~km}$ ), can be estimated by consistency checking of the seismic events: focusing of diffractions, continuity improvement of seismic reflections, easy interpretation of migrated reflections firstly in the time domain, and then in the depth domain. After validation of the velocity model for the two lines crossing the deep well Dumre-7, post stack depth migration has been applied to the other lines using the lateral and vertical velocity variations estimated along these two lines. Comparison between adjacent 2D seismic lines was then used to check the $3 \mathrm{D}$ consistency of velocity models.

\subsubsection{Structural Interpretation}

The 3D geometry of the structural model is now better constrained. The new depth migrated lines were successful in providing more realistic 1:1 scale 2D images of the structure. This model can be built by direct interpretation of these seismic images combined with the structural knowledge from time migrated seismic images. To illustrate this interpretation, the post-stack depth migrated section corresponding to the time migrated section AAP-06-96 is displayed in Figure 9 and can be compared with the time images displayed in Figure 6.

\section{Infra-Salt Architecture}

The base of the salt is well calibrated in the Dumre-7 well and can be traced laterally, in most directions. However, due to the lateral velocity changes, the geometry in the time sections is poorly constrained and is better constrained on the depth migrated lines. In addition, intra-salt out-of-sequence structures are evident on most of the lines and connect superficially to a major thrust surface which brings the Oligocene 


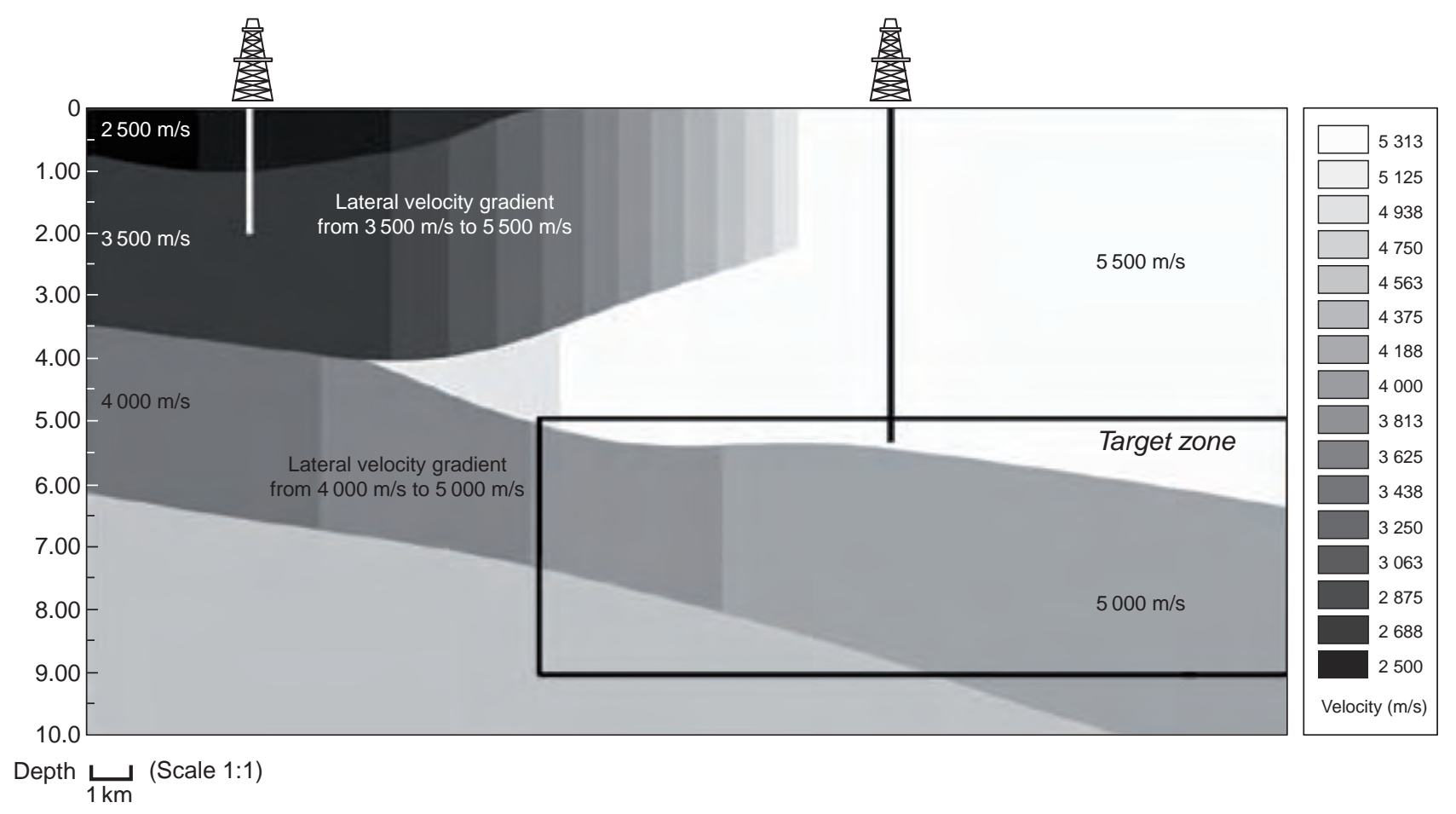

Figure 8

Depth velocity model estimated for the line AAP-06-96 describing the lateral and vertical velocity variations.

flysch on top of the Neogene molasse and has probably been encountered in some of the shallow Pekisht wells to the west.

\section{Top of Autochthonous Carbonate Series}

In most of the lines, deep reflections related to the autochthonous carbonate series can be traced from the foreland in the stack sections. However, only the top marker of the autochthon is finally preserved in the migrated lines, at about $7.5 \mathrm{~km}$ (4.5 or $5 \mathrm{~s}$ TWT), the deepest part of the seismic records being largely destroyed during the seismic migrations (time and depth processing).

\section{Intra-Flysch Detachment and Cut off of the Ionian Carbonates}

As evidenced in the regional seismic and structural transects, the Dumre block is located above a major transfer zone (i.e. the Vlora-Elbasan lineament), where the basal detachment of the Ionian allochthonous units jumps progressively from an intra-Triassic horizon in the south-east, toward shallower intra-Oligocene detachments in the north-west (Fig. 10). As the surface trend of this regional feature is approximately NE-SW, the cut-off of the Ionian allochthonous carbonates is assumed to extend in the subsurface, parallel to the northernmost surficial contour of the carbonates, at an unknown but probably discrete distance farther to the north-west (i.e. forelandward). The western part of the lines AAP-04-96, AAP-06-96 and AAP-07-96 images an east-dipping reflector between the top of the sub-horizontal autochthonous carbonates and the gently folded basal surface of the Neogene molasse (Fig. 9). We have interpreted this reflector as the intra-flysch detachment, which extends westward into the shallow Lushne anticline which involves the Neogene series. In contrast, this detachment is progressively deepening eastward, thus accounting for the involvement of the Mesozoic carbonates in the sub-salt allochthon, and a progressive tilting and rotation of overlying Tertiary horizons. The same intraflysch detachment is also imaged on the north-south lines AAP-11-96 and AAP-12-96 (Fig. 11). However, on other lines, the precise location of the cut off of the allochthonous carbonate on the basal ramp remains questionable. We assume that this lack of continuity of the reflections results from a drastic change in the dipping attitude of the carbonates, vertical or overturned beds of the frontal flank of the ramp anticline thus ensuring a lateral closure for the prospect.

\section{Architecture of the Ionian Carbonate Allochthon}

Numerous reflections can still be seen below the basal salt surface and are interpreted as the top of the Ionian carbonates (Fig. 9 and 11). The thickness of the intervening Oligocene flysch horizons seems quite anisopachous and may change 

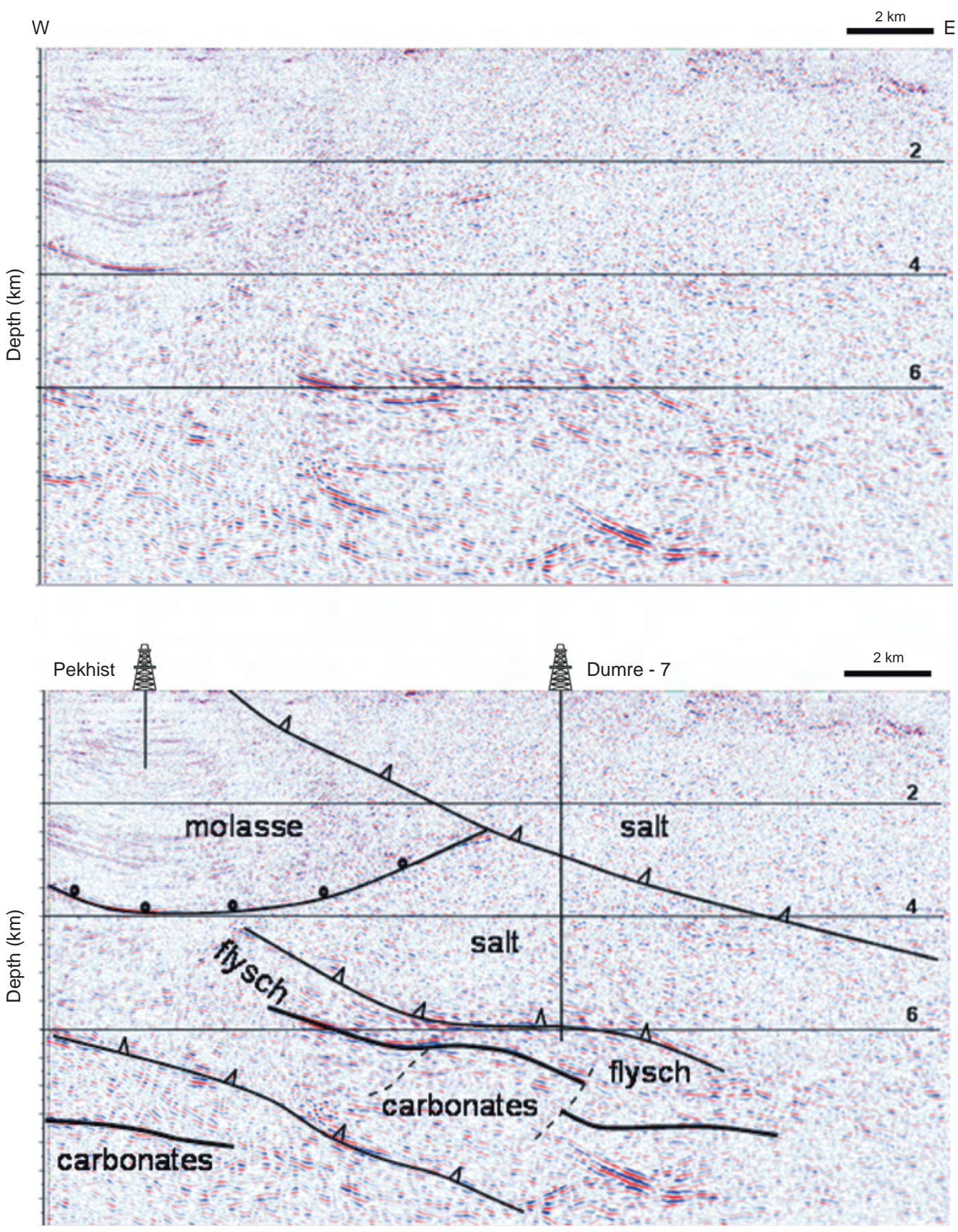

Figure 9

Depth migrated seismic image for the line AAP-06-96, without (upper) and with (below) interpretation.

greatly, depending on the structural interpretations. The depth contour map of the top of the Ionian carbonates was based on this interpretation (Fig. 12). Nonetheless, as indicated by the attitude of the basal salt contact, there is no structural closure at the present location of the Dumre-7 well, between lines 5 and 6 .

\subsubsection{Definition of a New Prospect}

The new depth migrated lines which provide better constraints on the $3 \mathrm{D}$ geometry of the structural closure, show that this structure extends to the northwest of the Dumre-7 well, the apex of the structure being now expected at a depth of 


\section{Dumre Structure}

Structural evolution cartoon

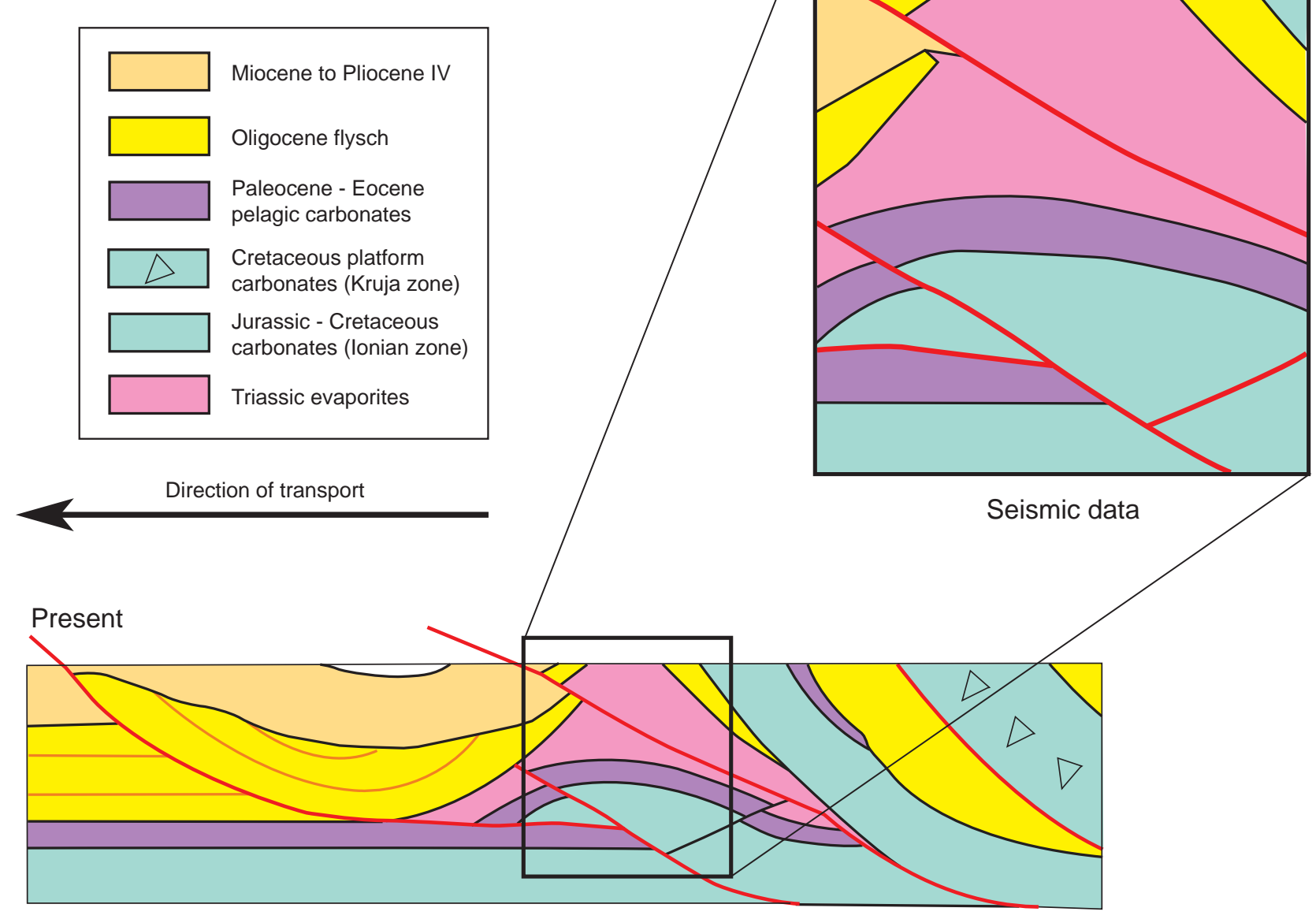

End Miocene

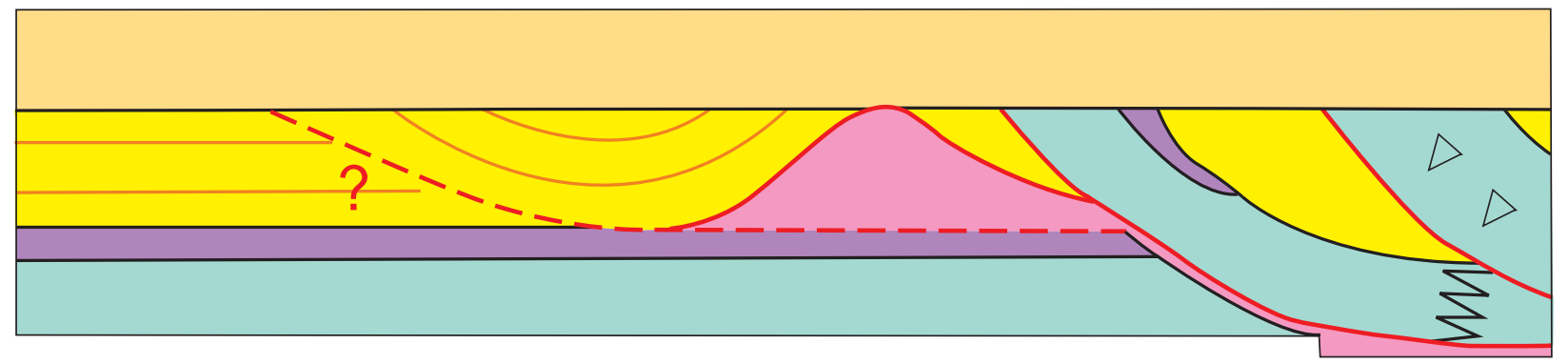

\section{Burdigalien}

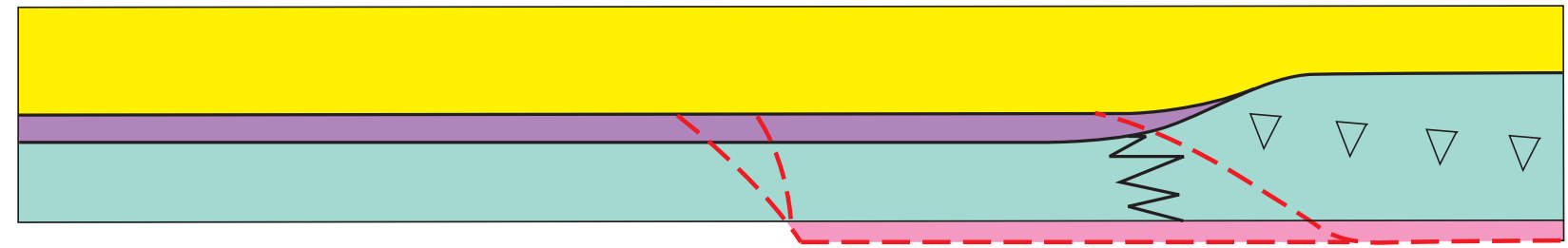

Figure 10

Schematic diagram outlining the geodynamic evolution of the Dumre block. 

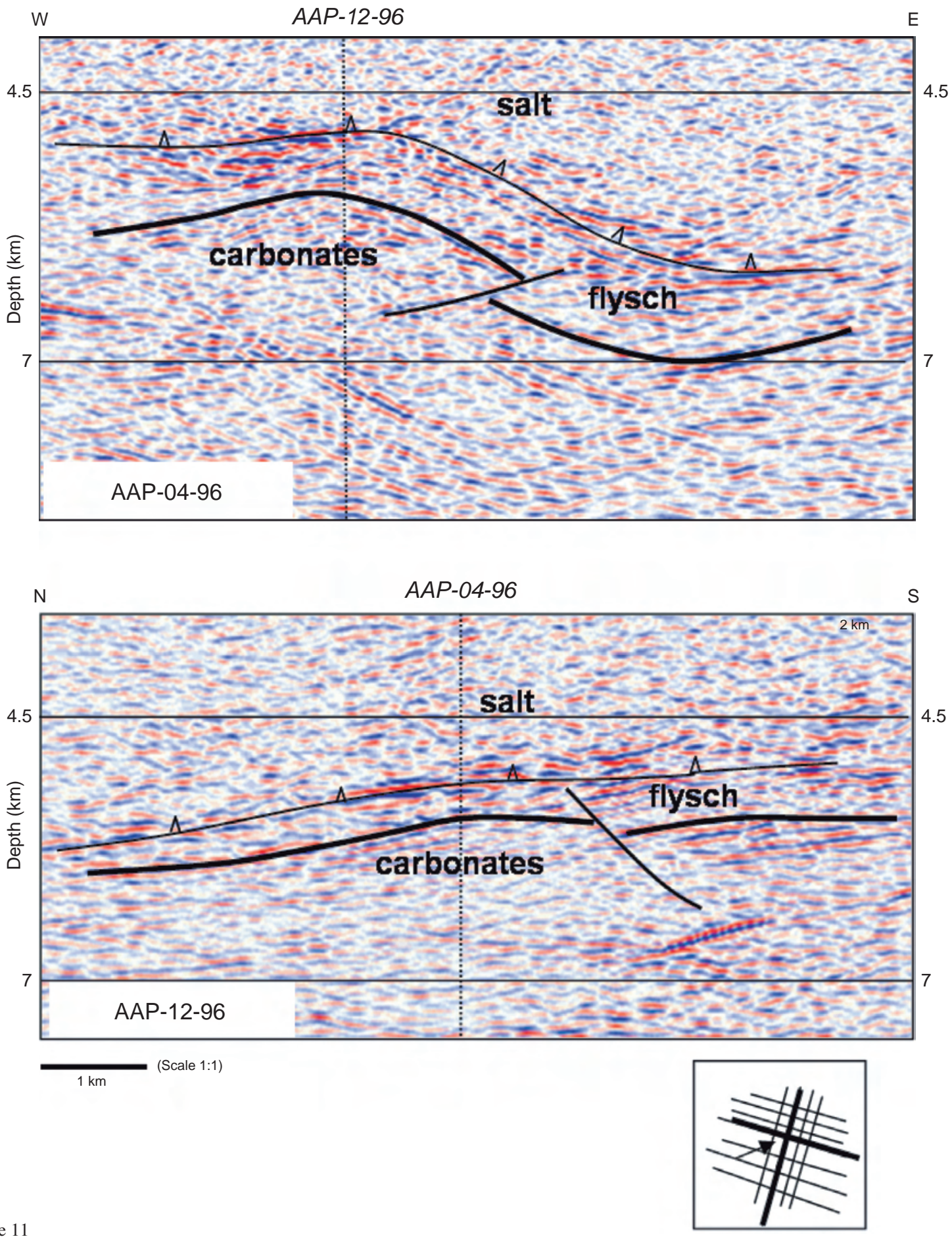

Figure 11

Depth migrated seismic images interpreted to define the new Dumre prospect: W-E line AAP-04-96 (upper) and N-S line AAP-12-96 (below).

approximately $5.5 \mathrm{~km}$, around the intersection between lines AAP-04-96 and AAP-12-96 (noted 4 and 12 in Fig. 12). A structural closure and a new prospect (an oblique anticline structure developed along the Vlora-Elbasan transfer zone) is therefore well defined westward of the previous location
(Fig. 12). The prospect documented here resembles a classic ramp anticline, with small antithetic southeast-verging backthrusts developing at the rear of the structure. Structural closure is evidenced both to the south and the east, but remains conjectural toward the north and the west. Hopefully, the 


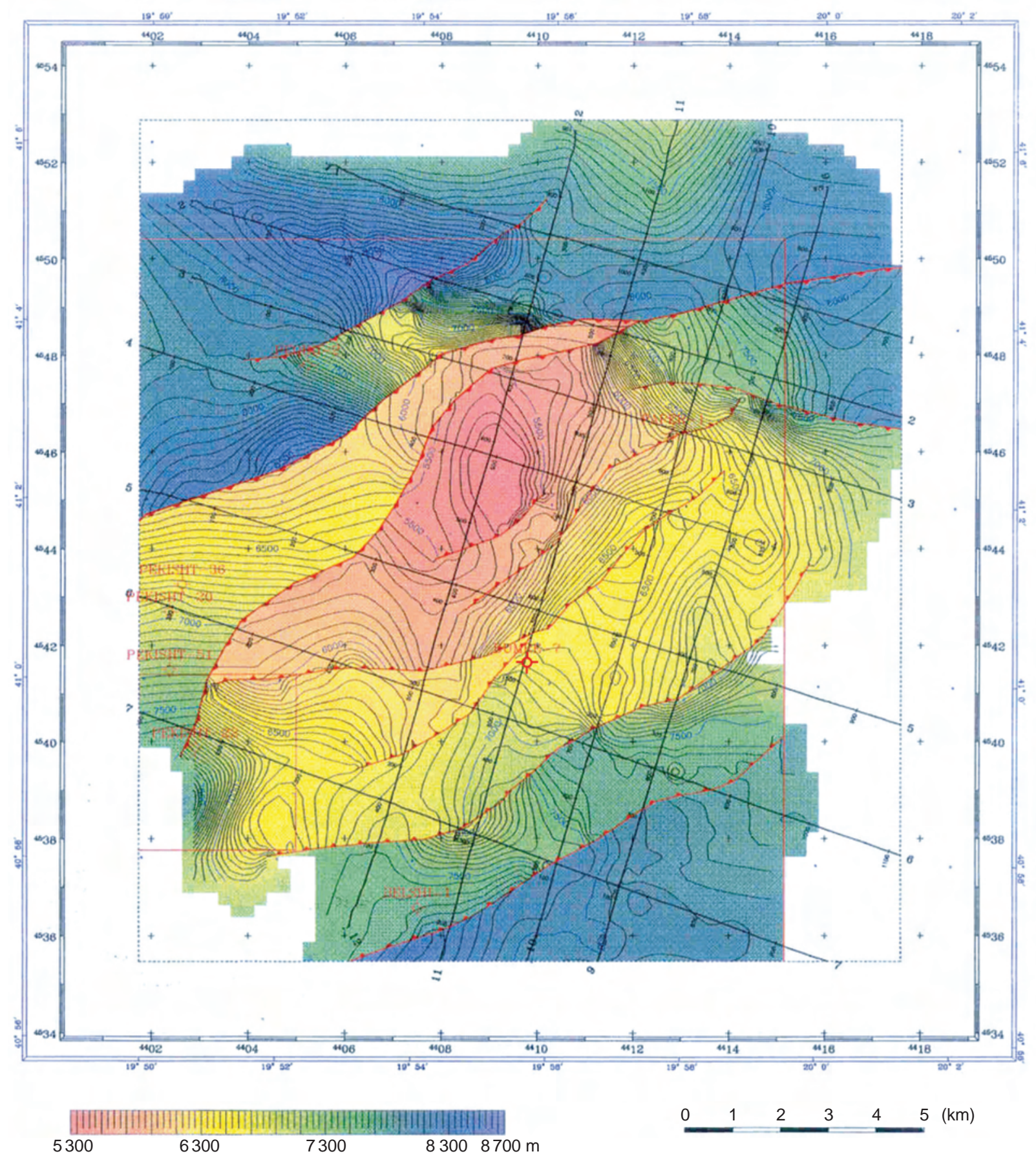

Figure 12

Contour map (isobaths in metres) of the Dumre prospect at the top of the Ionian carbonates.

carbonates will have a northwest-dipping attitude between the anticline axis and their cut-off along the basal detachment, thus insuring the lateral closure of the structure. The lack of continuity of the reflection is likely due to the steeply dipping attitude of the carbonates along the outer flank of the structure. The shape of the prospect is outlined in the subcrop structural map and the depth to the objective is expected at less than $6 \mathrm{~km}$ (i.e. less than in the Dumre well, with a smaller column of salt to be drilled). In order to more accurately define the shape and volume of the prospect, the main 
concern would be to identify the northern and western cut-offs of the Ionian carbonates on the basal detachment. Ultimately, the lack of lateral continuity of the reflections between the top of the structure and the thrust plane is assumed to relate to a very rapid change in the carbonates, with the development of a vertical or even overturned flank at the front of the structure.

\section{CONCLUSIONS}

Application of poststack depth seismic migration on 2D seismic lines in Dumre area has provided improved seismic images resulting in a more reliable 3D structural interpretation. Results led to a better understanding of the failure of the older exploration wells and to propose a new prospect. The conclusions of this integrated approach of depth seismic imaging indicate that the potential closure of the infra-salt Ionian carbonates is located to the north-west of Dumre-7 well. Nevertheless good quality seismic images of deep structures below the salt diapir and thrust sheets remains challenging in some areas even if poststack depth migration is applied where required in case of strong lateral velocity variations exist. A further improvement of the seismic images could still be obtained in the Dumre block, by integrating additional geological information and by initiating prestack depth migrations of the seismic sections, using the geological model built by poststack depth migration.

This study has shown that an interpretative approach of depth seismic imaging can provide a better estimation of the geological structures as it is required for better oil and gas potential evaluation through advanced basin modelling studies in complex areas (Vilasi, 2009; Thibaut, 2009). An integrated team of geologists and geophysicists was essential for combining geological knowledge and depth seismic imaging methods to build the required velocity models and interpret the depth migrated seismic images.

\section{ACKNOWLEDGMENTS}

We acknowledge the National Agency of Natural Resources of Albania for permission to publish the data, Jean Letouzey and Emily Albouy formerly from IFP Energies Nouvelles for contributing to the study. Thanks also to Anglo-Albanian Oil Company and Premier Oil for access to well and seismic data.

\section{REFERENCES}

Albertin U., Kapoor J., Randall R., Smith M., Brown G., Soufleris C., Whitfield P., Dewey F., Farnsworth J., Grubitz G., Kemme M. (2002) The Time for Depth Imaging, Oilfield Review 2.

Beche M., Kirkwood D., Jardin A., Roure F. (2005) 2D Depth seismic imaging in the Gaspé Belt, a structurally complex fold and thrust belt in the Northern Appalachians, Québec, Canada, in Thrusts Belts and Foreland Basins, Lacombe O., Lavé J., Roure F., Vergès J. (eds), Springer, Berlin, pp. 75-90.

Cabrera J., Celis V., Amalricua S., Araujo M. (1998) Experiences in depth imaging of Venezuelan data, Lead. Edge 17, 5, 1743-1747.

Gjermani I., Dhima S. (2009) Using the Seismic methods in the Ionian Zone where overthrust are present, 5th Congress of Balkan Geophysical Society, Belgrade, Serbia, May 10-16.

Jardin A., Chaker R., Krzywiec P. (2005) Understanding seismic propagation through triangle zones, in Thrusts Belts and Foreland Basins, Lacombe O., Lavé J., Roure F., Vergès J. (eds), Springer, Berlin, pp. 63-74.

Jardin A., Collaku A. (2004) Interpretative poststack depth imaging for seismic velocity model estimation in central Albania, $A A P G$ European Region Conference, Prague, Czech Republic, October 10-13.

Muller J., Ricarte P., Forgues E. (2000) An adapted 2D processing sequence for foothills data through synthetic examples, SEG Annual Meeting, Calgary, Canada, August 6-11.

Nikolla L., Kuneshka M., Ademi F., Bejtaj K. (2002) Development and structural styles of Albanides, www.akbn.gov.al.

Robein E. (2003) Velocities, Time-imaging and Depth-imaging in Reflection Seismics. Principles and Methods, EAGE publications.

Roure F., Nazaj S., Mushka K., Fili I., Cadet J.P., Bonneau M. (2004) Kinematic evolution and petroleum systems: an appraisal of the External Albanides, in Thrust Tectonics and Hydrocarbon Systems, AAPG Memoir 82, McKlay K.R. (ed), 24, 474-493.

Thibaut M., Jardin A., Sulzer C., Faille I. (2009) ISBA3D: Innovative solutions for 3D basin modelling in complex areas, 71st EAGE Annual Conference, Amsterdam, Nederland, Abstract W047, 4 pages.

Velaj T., Xhufi C. (1995) The evaporite effect in the tectonic style of the internal Ionian subzone of the Albanides, 57th EAGE Annual Conference, Glasgow, Scotland, 29 May-2 June, Abstract P574.

Velaj T. (2001) Evaporites in Albania and their impact on the thrusting processes, J. Balkan Geophys. Soc. 4, 1, 9-18.

Vilasi N., Malandain J., Barrier L., Callot J.P., Guilhaumou N., Lacombe O., Muska K., Roure F., Swennen R. (2009) From outcrop and petrographic studies to basin-scale fluid flow modelling: the use of the Albanian natural laboratory for carbonate reservoir characterization, Tectonophysics 474, 1, 367-392.

Final manuscript received in March 2011 Published online in September 2011 